\title{
Comparison of latex and nitrile glove on total bacterial colonisation on clinical students at the Department of Oral and Maxillofacial Surgery Faculty of Dentistry Universitas Sumatera Utara March-May 2018
}

\author{
Ahyar Riza, ${ }^{*}$ Rahmi Syaflida, Abdullah Oes, Arisya Fiqriyah
}

\section{Abstract}

Objective: Wearing glove is one form of self protection from blood, saliva and other body fluids secretion exposure or when health worker's hand in contact with patient's mucous membrane during treatment/procedure. The type of glove material could affect its ability to prevent bacterial contamination on hand and the most common type of gloves used are nitrile and latex based material.

Material and Methods: This is an experimental research with a post test only design approach. The sampling technique used is purposive sampling. In this study, sample were divided into 2 groups consisting of 18 clinical students wearing latex and nitrile gloves - performing dental extraction on either anterior or posterior tooth. Results: The mean results obtained from latex glove are $88.82 \pm 168.56 \mathrm{CFU} / \mathrm{ml}$ which is higher than the nitrile group $0.00 \pm 0.00 \mathrm{CFU} / \mathrm{ml}$. Based on the Mann-Whitney test results, the $p$ value $=0.01<0.05$ where there are significant difference between latex and nitrile glove.

Conclusion: Based on results of research and data analysis, it can be concluded that there are significant differences in the number of bacterial colonies in latex and nitrile gloves where the use of nitrile gloves are more effective than the latex gloves.
Department of Oral and Maxillofacial Surgery, Faculty of Dentistry, Universitas Sumatera Utara, Medan, Indonesia

*Corresponding to: Ahyar Riza, Department of Oral and Maxillofacial Surgery, Faculty of Dentistry, Universitas Sumatera Utara, Medan, Indonesia

ahyar.riza@usu.ac.id

Received: 26 August 2018 Revised: 10 March 2019

Accepted: 15 March 2019

Available online 1 April 2019
Keywords: Self protection, Gloves, Bacterial

Cite this Article: Riza A, Syaflida R, Oes A, Fiqriyah A. 2019. Comparison of latex and nitrile glove on total bacterial colonisation on clinical students at the Department of Oral and Maxillofacial Surgery Faculty of Dentistry Universitas Sumatera Utara March-May 2018. Journal of Dentomaxillofacial Science 4(1): 12-14. D0l: 10.15562/jdmfs.v4i1.795

\section{Introduction}

Nosocomial infections refer to any systemic or localized conditions that result from the reaction by an infectious agent or toxin. ${ }^{1}$

The dental work field is susceptible from the possibility of direct or indirect contact of infectious microorganisms in the clinical environment, therefore infection control is necessary in every procedures. American Dental Association (ADA) and Centers for Disease Control (CDC) recommends that every patient must be considered to be potentially infectious and standard precautions must be applied to reduce and prevent iatrogenic, nosocomial or blood-borne, and other infectious materials. Standard precautions include hand hygiene, self protection, aseptic techniques, sharp instrument management and working environment conditions. ${ }^{2,3}$

Wearing glove is one form of self protection from the risk of blood, saliva and other body fluids secretion exposure or when health worker's hand in contact with patient's mucous membrane during treatment/procedure. The type of glove materials could affect its ability to prevent bacterial contamination on hand and the most common type of gloves used are nitrile and latex based material. ${ }^{4}$

Study shows that nitrile gloves have a lower risk of perforation than latex, where latex provides the better protection if a perforation does occur. Nevertheless, the results may imply that latex based material has a superior barrier against bacterial transmigration in case of a microperforation than those made from nitrile. It was demonstrated that microperforation rates for examination and surgical gloves increase with increasing wearing time, with most of microperforations remaining unnoticed to the wearer.

A research conducted by Michael et al about gloves material properties on bacterial barrier efficacy in the presence of microperforation showed that latex provides the better protection if a perforation does occur.

\section{Material and Methods}

This study was an experimental study with posttest only design approach. The sampling method used in this study was Purposive Sampling, where the sample in this study was 36 undergraduate students at Department of Oral and Maxillofacial Surgery in Faculty of Denstistry, Universitas Sumatera Utara that are willing to participate in this study.

Samples were given an explanation about this research procedure and filled the informed consent 
Before the tooth extraction, samples were asked to wash their hands using antiseptic soap and dry with paper towel. Afterwards, samples where then given choice to wore either latex or nitrile gloves and proceed tooth extractions. After completing the extraction, the gloves were removed and the right hand is dipped in a sterile container containing $\mathrm{NaCl} 0.9 \%$ for 1 minute. Data obtained from this experiment was put into a table. Data processing was done with computer analyzed using Mann-Whitney test.

\section{Results}

The results obtained from Shapiro Wilk normality test are $p=0.000<0.05$ where the data is not normally distributed. Therefore the comparison between the two groups are followed by using Mann-Whitney test.

\section{Table 1 Data analysis using Saphiro Wilk and Mann-Whitney}

\begin{tabular}{lccc}
\hline Group & $\begin{array}{c}\text { Mean and Standard } \\
\text { Deviation }\left(10^{3} \mathrm{CFU} / \mathrm{ml}\right)\end{array}$ & $\begin{array}{c}\text { p-value normality } \\
\text { (Shapiro Wilk) }\end{array}$ & $\begin{array}{c}\text { p-value } \\
\text { (Mann-Whitney) }\end{array}$ \\
\hline Latex glove & $88.82 \pm 168.56$ & 0.00 & 0.001 \\
Nitrile glove & $0.00 \pm 0.00$ & 0.00 & \\
\end{tabular}

Table 2 Difference of mean urea level between test group and control group

\begin{tabular}{ccc}
\hline & Total bacterial colonies $\left(10^{3} \mathrm{CFU} / \mathrm{mL}\right)$ \\
\cline { 2 - 3 } 1 & Latex glove & Nitrile glove \\
2 & 0 & 0 \\
3 & 76 & 0 \\
4 & 208 & 0 \\
5 & 0 & 0 \\
6 & 16 & 0 \\
7 & 0 & 0 \\
8 & 474 & 0 \\
9 & 0 & 0 \\
10 & 0 & 0 \\
11 & 50 & 0 \\
12 & 550 & 0 \\
13 & 86 & 0 \\
14 & uncontable & 0 \\
15 & 49 & 0 \\
16 & 1 & 0 \\
17 & 0 & 0 \\
18 & 0 & 0 \\
Total & 0 & 0 \\
Mean & 1510 & 0 \\
& 88.82 & 0 \\
\hline
\end{tabular}

The mean results table 1 obtained from latex glove are $88.82 \pm 168.56$ which is higher than the nitrile group $0.00 \pm 0.00$.

Based on the Mann-Whitney test results table 1, the $p$ value $=0.001<0.05$ where there are significant difference between latex and nitrile glove. This shown that nitrile gloves are more effective in protecting against microorganism during dental treatment that latex gloves.

The absent of the bacterial colonies after using nitrile glove table 2 could be caused by the nature of nitrile gloves which are more resistant to leakage, able to maintain permeability, good durability and can be used for long working period where its attribute make nitrile based gloves more capable in protecting hands from microorganisms during dental work. ${ }^{7}$

\section{Discussion}

In this study, the gloves used were powdered latex gloves and non-powdered nitrile gloves, where the high number of colonies in latex gloves can be caused by the presence of its powder which can be a medium for bacterial growth for sweating hands. This conditions facilitates bacteria presence after use. Powder is sometimes added to gloves to help make it easier to put them on and take them off; however, powdered gloves are dangerous for a variety of reasons. In particular, aerolized glove powder on natural rubber latex gloves, but not on synthetic powdered gloves, can carry proteins that may cause respiratory allergic reactions. ${ }^{8}$

Another factor that could be the cause of the high average number of bacterial colonies in the use of latex gloves is the duration of use where with the presence of microporosity $\geq 50$ micron in diameter due to the factory production. The longer the gloves are used, the larger its microporosity as it increases in size and number without being realized by the user so that microorganisms easily enter through microporosity. ${ }^{9}$

\section{Conclusion}

Based on the results of research and data analysis, it can be concluded that there are significant differences in the number of bacterial colonies in latex and nitrile gloves where the use of nitrile gloves are more effective than the latex gloves. The absence of bacterial colonies after the use of nitrile gloves shows that nitrile gloves are able to protect from microorganisms therefore it is advisable to wear nitrile based gloves during dental treatment/ procedure. 


\section{Aknowledgment}

I would like to thank all the Lecturer Department of Oral and Maxillofacial Surgery, Ahyar Riza, Abdullah Oes and Rahmi Syaflida for guiding and helping me until the completion of this article.

\section{Conflict of Interest}

The authors report no conflict of interest.

\section{References}

1. Kouchak F, Askarian M. Nosocomial Infections: The Definition Criteria. Iran J Med Sci 2012;37: 72-73.

2. Suleh MM, Wowor VNS, Mintjelungan CN. Pencegahan dan pengendalian infeksi silang pada tindakan ekstraksi gigi di rumah sakit gigi dan mulut pendidikan PSPDG Fakultas Kedokteran UNSRAT. J e-Gigi 2015;3: 587-597.
3. Lugito MDH. Kontrol infeksi \& keselamatan kerja dalam praktek kedokteran gigi (Infection control and occupational safety in dental practiceI). J PDGI 2013;62: 25.

4. Mathur P. Hand hygiene: Back to the basics of infection control. The Indian J of Med Res 2011;134: 611-620.

5. Bardorf $\mathrm{MH}$, Jäger $\mathrm{B}$, Boeckmans $\mathrm{E}$, et al. Influence of material properties on gloves' bacterial barrier efficacy in the presence of microperforation. American J Infection Control 2016;44: 2,4,5.

6. Landers TF, Dent A. Nitrile versus latex for glove juice sampling. J PLoS ONE 2014;9: 1-3.

7. Garland KV. The benefits of nitrile. J Professional Excellence 2013;11: 12-6.

8. FDA. Proposal to Eliminate the Use of Powdered Gloves in Health Care Announced. Oncol Times 2016;38: 7.

9. Puranik SM, Mandroli PS, Gokhale NS. Comparative evaluation of microbial counts on hand after using surgical and examination gloves. Indian J Dent Adv 2013;5: 1164-1168.

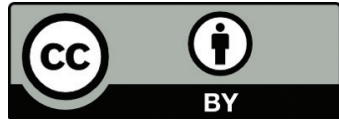

This work is licensed under a Creative Commons Attribution 